\title{
EPISTEME AND EXPERIENCES ABOUT PASHTUNWALI: THE STANDPOINT OF PASHTUN WOMEN OF KHYBER PAKHTUNKHWA, PAKISTAN
}

\author{
Latafat Aziz \\ PhD Scholar, Department of Sociology, \\ International Islamic University Islamabad, Pakistan \\ Rabia Ali \\ Assistant Professor, Department of Sociology, \\ International Islamic University Islamabad, Pakistan \\ Asim Muneeb Khan \\ Assistant Professor in Sociology \& Anthropology, \\ Department of Humanities \& Social Sciences, Bahria University Islamabad, Pakistan \\ Asim.soc1@gmail.com
}

\begin{abstract}
Pashtun societies are well studied by international and national scholars of Pakistan and Afghanistan. The existing scholarship largely presents a male perspective while explaining the nature, structure, and interpretation of Pashtunwali in Pashtun society. A rigid and fundamentalist view of Pashtun society is usually portrayed such as tarborwali, revenge, honor killings, etc. Our research work was focused specifically on the pashtun females' experiences and episteme of transmission patterns of Pashtunwali-Pashtuns cardinal code of conduct, among Pashtun women in Pakistan. This study was carried out in three districts of Khyber Pakhtunkhwa (KPK)—namely, Charsadda, Karak, and Swat of Pakistan. Thirty-nine (39) Pashtun women having diverse backgrounds concerning age, education, and locale were in-depth interviewed for data collection. The data was analyzed through the thematic qualitative data analysis technique using Standpoint feminism (Sandra Harding and Dorothy Smith) as a major theoretical guide. The study has revealed the endowment of Pashtun women (especially mothers, grandmothers, and mothers-in-law) in preserving, sustaining, and transmitting the Pashtun value system towards the young generation (daughters). Unconditionally, Pashtun women (especially mothers) had a significant role in the creation and promotion of Pashtun culture through folklores, proverbs, songs, dress code, arts, literature, and by cooking traditional cuisine, etc. In Pashtun culture, notions of honor, dignity, and shame are described as driving fuel behind all cultural values and structures. The study reflected the perspective of Pashtun women that they were appreciative and insightful about the meaning, history, and cultural composition of Pashtunwali and their identity but at the same time, they were not benighted about the contemporary emerging challenges that have been faced by traditional Pashtun culture. Pashtun women highlighted that Pashtuns are ghairatmand -mind their words and commitments and never compromise on the basic principles. They emphasized that it is necessary to reconsider and revisit social heritage to better reflect on the changing notions and demands of the contemporary age. Hujras/Baithaks have been identified as the most celebrated and accustomed places in Pashtun society.
\end{abstract}

Keywords: Pashtunwali, Pashtun Women, Standpoint, Experiences

\section{INTRODUCTION}

The idea of Pashtunwali has attracted the attention of several local and foreign anthropologists who have provided a detailed account of the Pashtuns' way of living and the significance of Pashtunwali for them. Pashtun culture is backed by the "Pashtunwali" which, in a real sense deciphered as the "the method of the Pashtuns", is an unwritten code of honor that is necessary to have Pashtun identity. Pashtunwali is an ideal that can be translated as an ethnic self-representation of the Pashtuns (Alam et al, 2014; Bokawee, 2006; Anderson, 1979; Atayee, 1979). Pashtunwali is the code of life as comprehended, interpreted, and rehearsed by Pashtuns. It is the center of social conduct for 
Pashtuns - translated as the way of the Pashtuns. It is a set of customs, cultural codes, and values that regulate the Pashtun society and has been previously discussed in detail by various authors (see Alley, 2012; Benson \& Siddiqui, 2014; Hawkins, 2009; Yousufzai \& Gohar, 2005; Kakar, 2004; Spain, 1972).

There are multiple studies available on how the Pashtunwali is understood by Pashtuns (see Bartlotti, 2000; Saeed, 2012; Khan et al., 2020). The majority of such scholarly work has engaged ethnographic text that provides a rich account of the Pashtun culture. However, the available literature on Pashtunwali is largely male-centric and fails to engage with women's perspective and their standpoint when it comes to the discussion of Pashtunwali. The majority of the existing studies (see Ahmed et al, 2017; Akins, 2018) focused on Pashtuns in Pakistan's tribal regions where men remain the focus of attention and women remain invisible. Pashtun women have been denied the principal rights and legal position which Islam has defined for them in different spheres of life (Qadeer, 2014). This very notion of invisibility is also evident from the studies conducted on Pashtunwali which have largely ignored how Pashtun women experience Pashtunwali differently.

To fill this gap this paper highlights Pashtunwali from the standpoint of Pashtun women. Detailed encounters with Pashtun women in different parts of Pakistan unveiled the experiences of Pashtun women (being a daughter, mother, and grandmother), attitude formation, nature of the relationship, level of understanding, patterns of interaction, and construction of their self-identities under the heading of a meaningful relationship between mother-daughter, grandmothergranddaughter, and mother-in-law and daughter-in-law that contributed a lot in comprehending and interpreting the Pashtunwali among Pashtun women of various age groups (young adult, middle-aged adult, and old-aged adult).

Additionally, we have also considered the feminist epistemological standpoint. We have attempted to place the orientation, knowledge, and lived experiences of Pashtun women about the traditional and moral code of Pashtuns-Pashtunwali at the nucleus of our research. Likewise, Dorothy Smith's standpoint theory offered a valuable methodological strategy to explore the power dynamics that are organized and experienced by women in a given social context (Naples \& Gurr, 2013).

\section{Objectives of the Study}

To explore the meaning of Pashtunwali to the Pashtun women.

To analyze the experiences of older \& younger Pashtun women about Pashtunwali.

\section{Research Question}

How do Pashtun women understand, interpret and experience Pashtunwali?

How do Pashtun women describe Pashtu proverbs on basic principles of Pashtunwali?

\section{REVIEW OF LITERATURE}

Several studies have been conducted on Pashtunwali in the context of Pakistan and Afghanistan (e.g. Benson \& Siddiqui, 2014; Alley, 2012; Hawkins, 2009; Yousufzai \& Gohar, 2005; Kakar, 2004). The majority of these studies have examined Pashtunwali in reference to the war on terrorism. It has been found that inside Pashtun society, the qualities, standards, and principles of Pashtunwali have been transmitted orally for a considerable length of time.

A thorough analysis of the existing scholarly work reveals that the role of Pashtun women in Pashtunwali is minimally concentrated and even less comprehended. Much has been expounded on the mistreatment of women in Afghanistan, and it is normally credited to Pashtun ancestral practices, for example, male older folks had to say over deciding fate (marriages and carrier) of young women; high pride price, walwar, presented to the father of the bride and proposing the sale of women into marriages and honor killings of women for sexual unfortunate behavior. Among the enormous Pashtun landowner (zamindar) class and the city-abiding Pashtuns, the disengagement of women is pervasive and the chader or boghra are worn when the lady leaves the bounds of her family compound. Females are compelled by the Pashtunwali code from various perspectives that it is hard to comprehend why they take an interest in this framework, or why, when women's rights are talked about, they oppose them, even those related to social insurance and education (Kakar, 2003). 
In 2017, Ahmed et al, conducted an extensive study on Pashtunwali and its representation in Pakistani advertising, and findings for the study pinpointed multiple elements of Pashtun culture like Pashtunwali, hujra, atan (traditional Pashtun dance), respect, the status of elders, and music depicted in selected eight TV ads. The study found that portrayal of Pashtun women and their role was quite passive in respective TV ads as they were shown behind the curtains and separate from the public sphere as they believed to belong to the private sphere-this depiction of Pashtun women was quite indifferent to their role models like Begum Naseem Wali Khan and Malalai of Miawand (Qazi, 2009).

Indeed, even Pashtun men admit in their private life as "khazay ajaiz qam day, be wasa de" for example "the majority of women is hopeless, they are powerless" (Akbar, 2013). She has been denied of a few activities in everyday life which are additionally permitted by Islam for example their assent isn't looked for marriage; they can't claim divorce compensation; legacy in land and other is denied to them; they can't separate from their spouses. There is a proverb in Pashtu about women as, "khazza ya de kor da, ya de gor da" - which implies that for a "lady either the house (kor) or the grave (gor)" (Akbar, 1988). It expresses that ladies face extraordinary confinements and hardships throughout her life. Then again, Mour (the mother) is the image of celebrated status and enthusiastic impact in Pashtun society. She is thought to be an expert on Pashtunwali and also an honest to goodness guardian (Ahmed, 1980).

In 2004, Aminah Ahmed studied the public activities of Pashtun women or Bibiane (pl. of the Pukhto expression 'Bibi': woman) from landed, wealthy families in the districts of Swat and Mardan in northern Pakistan. The broadly utilized Pushto term Gham-khadi both alludes to explicit segregated social gatherings such as memorializing death, marriage, birth, and other such occasions and assigns the feelings of distress ( $\mathrm{gham}$ ) and delight ( $k \mathrm{hadi}$ ) which they inspire. Readiness for and participation at gham-khadi occasions is privately comprehended as 'ladies' work', a lot of complex exercises indispensable to Pashtun personality or Pashtunwali. Conventionally, essayists on Muslim social orders, especially the Pashtuns, have described Pashtunwali as a 'perfect sort code' given such standards as Badal (vengeance), melmastia (neighborliness), nanawatee (shelter), tor (female respect), and tarboorwali (agnatic competition) (Ahmed, 1980). She recommends that gham-khadi has come to expect a need among Pashtuns as a contemporary standard of Pashtunwali.

To sum up, despite the rich literature on Pashtunwali, there is a clear gap that needs to be filled. It is important to understand and acknowledge the role played by Pashtun women not merely sustaining the Pashtunwali but also their role in transmitting it to the next generation.

\section{MATERIALS AND METHODS}

The present research was qualitative in nature. The qualitative research method is employed to have an in-depth understanding of the lived experiences of Pashtun women and their episteme about the Pashtunwali. The research was carried out in three districts of the Khyber Pakhtunkhwa, Pakistan namely, Karak, Swat, and Charsadda. The study population consisted of Pashtun women of various age groups including young adults, middle-aged adults, and old-aged adults. Thirty-nine (39) respondents (selected with the help of a consecutive sampling technique) were interviewed with the help of an interview guide. The data were processed and analyzed using the thematic analysis technique. In the present research, one of the defining and key indicators/variables among the sociodemographic profile of our respondents is the social status of the Pashtun women. It is worth mentioning that Pashtun women were interviewed and studied concerning their social status (ascribed status) being a daughter, mother, grandmother, daughter-in-law, mother-in-law, and granddaughter to better understand the construction of their self-identities, experiences and comprehension about Pashtunwali

\section{RESULTS AND ANALYSIS}

The study has revealed important insights about the experiences of women (see Harding, 1991; Smith, 1997; Hebblethwaite \& Norris, 2011) and the orientation of Pashtun women and their comprehension of Pashtunwali. The research findings revealed that most of the Pashtun mothers were of the view that the importance of female education has been realized by parents that education of the female is education for the entire family. Moreover, young Pashtun women were optimistic about the use of modern ICTs. Young Pashtun women (Mothers and daughters) presented their strong emphasis on 
providing education to the new generation of Pashtun girls (Khalid \& Mukbtar, 2002). They believe that education opens up multiple opportunities for females.

In the current research, one of the defining and key indicators/variables among the sociodemographic profile of our respondents is the social status of the Pashtun women. Social status is a relative position which one holds within a social group. By the same token, several protocols, responsibilities, expectations, obligations, and duties, etc. (defined as role) are attached with that social status or position in society. In 1963, Swinehart conducted research on the subject of socioeconomic level, status aspiration, and maternal role in America and highlighted various responsibilities, expectations, and duties that are attached to mothers. Although that research was quantitative in nature and socio-economic status of mothers was one of the defining variables. The present study is guided by feminist standpoint theory as experiences of Pashtun women (being a daughter, mother, and grandmother), attitude formation, nature of the relationship, level of understanding, patterns of interaction, and construction of their self-identities have been studied under the heading of a meaningful relationship between mother-daughter, grandmother-granddaughter, and mother-in-law and daughter-in-law. It contributed a lot to comprehending and interpreting the generational relations and transmission of Pashtunwali among Pashtun women of various age groups and generations.

One of the key findings of this study is the fact that Pashtunwali is not rigid and static but dynamic and transformative in nature. Pashtunwali as a symbolic framework is adaptable. It has become evident that it can be utilized, molded, developed, and deconstructed with the passage of time in Pashtun societies. Previous scholarship on Pashtunwali has focused only on fixed and constructed notions of Pashtuns' ethnic identity, jirga system, authority, and dominant values of Pashtunwali such as hospitality, honor, revenge, and rivalry, etc. at length and ignored the transformative perspective of Pashtunwali that how Pashtuns adapt to the changing trends and lifestyles (Ahmad, 1976; Ahmad, 1992; Barth, 1965; Dupree, 1978; Sanauddin, 2010).

The research findings revealed that the majority of the Pashtun women, irrespective of their socio-demographic background, identified multiple traits and principles which are recognized, practiced, and transmitted among Pashtun women throughout generations. These principles are defining the theme of their cultural heritage. Pashtun women consider their social heritage as something which is an ultimate source of knowledge, morality, and self-identification. They were very ethnocentric about their traditions, history, and ancestral values which are defined and practiced through ages. One of our interviewees-Asiya Bibi, old-aged adult, married, educated from Karak expressed the detailed notion of Pashtunwali as:

Talking about the Pashtuns, in my point of view, Pashtuns are brave people. They are Ghairatmand, respectful and dignified people. I am proud to be a Pashtun woman. There are various factors behind that. A few of them are the moral standards, modesty, bravery, hospitality, and humbleness. Pashtun women can sacrifice their life for the sake of their family, village, tribe, and country. Akhpala Pashto saar taa rasawai (She complies with the standards of Pashtunwali). A Pashtun woman knows to respect her cultural and social norms). Pashtuns are no doubt very hospitable. The concept of nanawate (providing shelter) even to enemies when they seek help for settling the disputes (Personal Communication, 0409-2019).

The majority of young Pashtun women reported close relationships between Pashtuns and Pashtunwali. They affirmed that Pashtuns are the people of principles. They are watchful about their elders' practices and character in confirming Pashtunwali and related traits. One of the young adultsMaria, single, educated from Karak presented views about Pashtunwali and disclosed that Pashtuns learn and internalize those principles from their ancestors:

Pashtuns are the people of principles. We get these principles from our ancestors and our society. It is part of our culture to respect elders and we follow our traditions wholeheartedly (Personal Communication, 04-09-2019).

Another respondent-Tanzila, an old-aged adult, married, uneducated from Karak narrated various traits of Pashtuns such as revenge, hospitality, and Ghairat. She was very ethnocentric in her attitude towards Pashtuns' code of conduct as: 
Revenge, Hospitality, and Ghairat are among the major characteristics of Pashtun tribes. I am proud to be a Pashtun woman, and this is something I feel like a special status in my society (Personal Communication, 10-09-2019).

It has also become phenomenal from multiple viewpoints generated by Pashtun women about Pashtunwali, closely associated with the family system among Pashtuns. They disclosed a strong connection between Pashtunwali and the role of their family system (its essence) in defining, adapting, transmitting, and internalizing that respective code of conduct.

The majority of the respondents confidently expressed several meanings of Purdah which are practiced, attached, and sustained by Pashtun women. Several respondents reported that from an early age they were socialized to carry traditional and modest dress codes. They have shared their observations that they have always found their mothers, grandmothers, and other female members of their family quite disciplined in observing Purdah by wearing modest and elegant dress codes. In Pashtun culture, both women and men are always told and retold about their roles, boundaries, obligations, and protocols which are attached to their socially constructed identities by their elders.

In the Pashto language, the word Sattar (Purdah) is used in the context of observing Purdah. Observing Sattar has become seasoned in the roots of Pashtunwali and Pashtun women. In Pashtun culture, both women and men are always told and retold about their roles, boundaries, obligations, and protocols which are attached to their socially constructed identities by their elders. Both women and men are considerate about their interaction, mobility, and adherence to desired behavior and attitude expected out of them at an individual and communal level.

One of the senior-most respondents (aged 98), widowed, living in a joint family system from Karak explained the concept of Purdah and modesty. She reflected the ideal character of Pashtun women - the one who strictly observes Purdah and remains loyal to her husband. She also recalled her everyday life experiences (married life) and practices regarding her household activities and mobility. She emphasized that women were very much disciplined and mindful about their movement and even when they intended to visit their maternal home, they tried to travel/move during defined timings (wanted to be invisible and unidentified by the public during their mobility). The reason behind such practices was again backed by the concept of female seclusion and segregation. Pashtun women were also informed about their limits and boundaries (interaction with male relatives and family members). She further stated that:

Pashtun women are very modest. They strictly observe Purdah and remain loyal to their husbands. In our times, we used to observe Purdah, strictly. Usually, we stayed home and remained busy in household activities but whenever we had to visit the maternal home we tried to travel in the early morning or at Isha's (Late evening praying) time. We used to have Sattar (Purdah) from our maternal uncle's sons, paternal uncle's sons, and even from our brother-in-law (Personal Communication, 06-09-2019).

Considerably, young Pashtun women were also informed about the meaning, structure, and rationale behind the concept of Purdah in Pashtunwali. They affirmed that irrespective of gender and social identity - one is supposed to wear or carry the dress that should cover one's body. Young Pashtun women have also identified the transitional phase of Purdah and practices which were different from their mothers and grandmother's time. They were of the view that elder Pashtun women were quite strait-laced in their practices, especially in observing and sustaining Purdah. Not only in terms of specific/ traditional dress code but also exercised on all occasions (private and public level). But now that strictness has lowered among the new generation (young adults) and they have got multiple options (regarding modest dressing) and ways (modern trends and fashion) to wear chaddar as per their choice and taste. One of the young adults-Maria, educated, single from Karak shared her understanding about the Purdah and identified the transitional phase of Purdah and practices as:

Regarding Purdah, I believe that Purdah is of utmost importance in Pashtun culture. And you are supposed to wear the dress that should cover your body since it's part of religious and cultural traditions. There was a lot of strictness on Purdah a decade or two ago but now that strictness has lowered and people are choosing to wear chaddar as per their choice (Personal Communication, 04-09-2019).

In Pashtun society, the family institution is considered an important guardian of Pashtun culture and the identity of Pashtuns. Pashtun women are very much conscious and concerned about 
their families, relationships, and traditions. They acknowledge core values of patience and sacrifice as building blocks of Pashtun culture (Idrees, 2005). Most of the Pashtun women declared that the family system plays a decisive role in defining an individual's identity. Pashtun women have always credited their family system as a binding force for them. Parents and elders are highly praised among them. Relationships are weighed throughout generations. Pashtun women are very concerned about the concept of peace and prosperity. Most of the time, they associate happy and healthy relationships with the strong base or existence of the family system.

The majority of the respondents referred to their experiences about Jirga proceedings and their structure (held in the near past) and recalled the details and agenda points too. It shows that Pashtun women have understood the Jirga as one of the deciding elements of their cultural system. Critically, they evaluated the status of men (elders) in Jirga and the absence of women in Jirgarelated matters. But they also knew how to exercise their agency while listening to their male counterparts before the Jirga settlement and after they return home-they do share their thoughts, especially with elder women (grandmother, mother, and mother-in-law). While sharing her stance on the nature and structure of Jirga, another young adult respondent- Maryam, single, educated, from Karak expressed her understanding as:

In the Jirga system, elders are given high esteem. They play a defining role in conflict resolution among various groups. Due to the lengthy and complicated nature of the court and justice system, people prefer to call Jirga and get their issues resolved efficiently. Both parties are bound to obey the terms and conditions applied by the Jirga. Recently, we had a Jirga in our family about deciding the matter of custody of our cousin's son (as she got divorced). Previously, both parties went to court for their dispute, but they were not satisfied with the court proceedings. The issue was resolved by Jirga and they accepted the decision. The history of the Jirga tradition is old as well connected with Pashtun (Personal Communication, 06-09-2019).

It is well understood by the discussion with Maryam that Jirga has a pivotal role in conflict resolution. Jirga also serves as a means of getting speedy justice. But the problem, that most of the females shared, is less or no role of women within the Jirga system. For the respondents, the nonrepresentation of women often leads to partial decisions, especially in the context of women. The majority of the respondents were of the view that women are excluded from Jirgas (considered as male domain) and they are expected to accept the decisions taken in a Jirga. For example, the following views are taken from an excerpt with our discussion with Asiya Bibi, an old-aged adult, married, educated from Karak:

The Jirga system is also a very important factor in Pashtun culture and usually, the major decisions are taken there. Jirga is usually headed by the elders of the family and society and their decisions are highly respected. Usually, the age factor is the deciding element to head the Jirga. Women have nothing to do with the Jirgas, but women do have to accept the decisions taken in a Jirga. Not even the name of the woman is mentioned in the Jirgas (Personal Communication, 04-09-2019).

Another interesting narrative has been disclosed about the transition of the Jirga system in Pashtun society. Most of the respondents pinpointed the changing trends among Pashtuns living in urban areas or settlements about the nature and effectiveness of Jirgas. They were of the view that due to modernization and technological advancement, the Jirga system is losing its worth because of its dependency on modern mechanisms of dispute resolution such as police and legal court systems. Young Pashtun women are more independent in their expression and decision-making nowadays.

Young Pashtun women were knowledgeable about the historical background of the Jirga system and they had shared numerous accounts of Jirgas which were shared by their mothers and grandmothers. They pinpointed that due to urbanization, the majority of Pashtuns are less concerned about calling Jirgas for dispute resolution or take the advice of elders concerning their familial issues or stakes.

Many of our respondents identified various factors behind the decline of Jirgas such as intolerance, individualism, financial independence, self-interest, modernization and cost, and benefits analysis, etc. Though women in the Pashtun communities reported not to be directly involved in Jirga proceedings, elder Pashtun women were of the view that their male counterparts usually seek their stance before going for Jirga even in some cases, the male members also shared Jirga proceedings 
and experiences with their female members of the family. It is quite evident through the discussion with respondents that urban Pashtuns are lesser into the Jirga system, but the Jirga system still maintains the status-quo in rural Pashtun areas.

Pashtun women are mindful of their social and religious identity. It has been observed that the majority of the old-aged adults identified that they are considerate about transmission and propagation of religious belief systems and cultural traditions towards the next generation. Considerably, Pashtun women give priority to religious traditions and rituals over their moral and cultural code of conduct (Pashtunwali) practiced over centuries.

Pashtun women explained that the role of parents and elders in defining their roles, responsibilities, and construction of their worldview is associated with them being female adults. The more interactive relationship between the different generations the better opportunities will be there for the learning. They have also pinpointed that the way their mothers and grandmothers used to share their lived experiences and skills guided them to better understand and realize their responsibilities and face the problems that emerged during the transitional phase of life (entering into adulthood). One of my old-aged respondents-Rehana, married, a homemaker from Karak emphasized the role of parents and grandparents in defining her roles and responsibilities being a Pashtun mother. She further narrated that her grandparents used to share their life stories and experiences which helped her a lot to cope up with the emerging challenges - one faced during identifying one's adulthood and shared as:

We had a great childhood spent together with other family members. We used to play a lot in our childhood at our homes, but we were not allowed to go out and play after the age of puberty. Our elders always used to share their life stories and practical experiences with us. Such experiences helped us in our adulthood to find out a way concerning the situation (Personal Communication, 04-09-2019).

Noticeably, Pashtun women expressed their feelings about the love and admiration they received from their parents being a daughter. They presented that from the early stage, Pashtuns socialize their children about the concept of showing great respect towards elders, and similarly, children are treated with great affection and love. Children are always considered as a true source of blessing from Almighty Allah and parents are always considerate about the needs and desires of their children.

Truly, education is an important tool to devise the norms and constructs reality. Several educated Pashtun women shared their experiences about the role of education in defining and reshaping gender norms and women's agency in Pashtun society. They were of the view that Pashtun women are well-informed about their true potential and strength. Now Pashtun women are exhibiting their skills and knowledge in various fields of mainstream society. By the same token, they never compromise on their basic familial values and traditions passed through generations. One of the young Pashtun women-Saleema, married, educated, serving as a computer operator, living in a joint family system, from Charsadda reflected the role of education in reshaping gender norms and women's agency in Pashtun society. She shared that an example of her elder sister who was a highly educated woman (earned respect a lot) and the way she has set an exemplary model for other Pashtun women to follow. She stated as:

My elder sister who is a Ph.D. made her way to Ph.D. when there was no concept of education beyond $10^{\text {th }}$ grade for females. She is having a very good job as well. Seeing her in a good position due to education has opened up ways for many women in our area. I criticize some of the elements of the Pashtun culture meanwhile I am proud to be a Pashtun too. Modesty is an important element of Pashtun culture (Personal Communication, 28-11-2019).

Remarkably, most of the young Pashtun women were knowledgeable about the importance of acquiring education. They acknowledged that their parents are considerate about their daughters' education. Pashtun women mentioned that their parents also considered their opinions and interests regarding education and career. The majority of the young Pashtun women shared that now families are in favor of daughters' education and also allow and encourage their daughters to pursue their dream of getting higher education. They also disclosed that traditionally Pashtun people were reluctant about the females' education. One of the young adults-Irum, educated (having a Bachelor's degree), single, student, living in a joint family system from Karak highlighted concerns about the female's education. She shared that religion has an important place in the Pashtun cultural context and parents are very concerned about imparting religious knowledge to their children. Furthermore, she 
emphasized that it is inevitable for the young generation to deny or decline the importance of acquiring knowledge and basic skills that are highly required to cope up with the modern age of technological advancement. She stated as:

Nowadays there is a special focus on the importance of females' education since it is being realized that the education of the female is education for the entire family. Religion has a very important role in the Pashtun cultural context. When it comes to technology, I think it's for our benefit. Now it's up to us, how we utilize modern ICT. It will have relevant consequences accordingly (Personal Communication, 09-11-2019).

The majority of the Pashtun mothers were of the view that the importance of female education has been realized by parents that education of the female is education for the entire family. A considerable difference was found to be in the opinion of the grandmothers, mothers, and young daughters concerning the provision of education to females. Young Pashtun women (Mothers and daughters) presented their strong emphasis on providing education to the new generation of Pashtun girls. They believe that education opens up multiple opportunities for females. The elder Pashtun women were of the view that during their adulthood, there may be chances for them to survive without formal education but now it's nearly impossible for women to survive without education.

In Pashtun culture, women have a very special place in society. Pashtun women were very much concerned about the orientation and manifestation of their roles and responsibilities. Pashtun women were also thoughtful about their traditions and practices which are disseminated and conveyed by elders. Most of the educated Pashtun women were impassioned about their cultural heritage and identity being a Pashtun woman. One of the highly educated respondents-Sadaf, a middle-aged adult, single, serving as a lecturer, living in a nuclear family system from Charsadda expressed her thoughts about the cultural identity and roles associated with a Pashtun woman. She shared that education has made her heedful about her identity, intentions, and passions. She emphasized the role of education in moderating various viewpoints among Pashtuns. She was of the view that her family (especially her father) has always encouraged her in pursuing her dream of getting an education. She also shared one of the famous Pashto proverbs about the importance of cultural heritage and identity (she usually shared with her students too) as Waye che day Kalia ouza, kho da narkha aye ma ouza (You may migrate from your village, but do not forget your roots). She stated her views as:

I am proud to be a Pashtun woman. I think I get the utmost respect from my culture being a Pashtun woman and it is a myth that Pashtuns are very hostile towards ladies. Our family is different from the traditional and conservative Pashtun family since my father and maternal uncle were among the first educated people of their time. We were never discriminated against based on gender rather our father encouraged us to face the culture and society. We were told about cultural practices, but I was never forced by my father or elders to observe purdah, but we were told our limits too (Personal Communication, 27-11-2019).

Pashtun women are very concerned about their relationships and expectations associated with their social standing in society. Elder Pashtun women also endorsed the basic philosophy behind blood ties. Correspondingly, they emphasized the role of parents and elders in defining and interpreting the status of patrilineal and matrilineal kinship ties, especially lineage. Several interviewees have defined the notion of Tarbor as a title or name given to one's rival or opponent and it is not necessarily one's cousin. Likewise, Tarborwali is also associated with feelings of hatred, rivalry, competition, and stubbornness between and among relations. Pashtun women identified property matters as one of the major causes of tarborwali, especially within the close relatives. They were of the view that monetary lust leads towards tarborwali. Most of the time, tarborwali is also defined as one of the dangerous forms of enmity among Pashtuns. It is also associated with feelings of hatred, rivalry, competition, and stubbornness between and among relations. For example, if two brothers are very considerate and friendly but if there comes a property or inheritance-related issue raised between them, if it turns into competition, impatience, or stubbornness, unfortunately, they will react like tarbors.

In Pashtunwali, hujra has been considered as one of the fundamental institutions of translating and maintaining the basic value system among Pashtuns. It is a commonplace where guests are welcomed, honored, and accommodated, irrespective of their socio-economic background. In previous times, when people used to travel to far-flung areas then upon arrival they used to sit and gather in hujras where they shared their experiences and information with other fellows. 
The majority of the respondents reported that hujras proved to be a melting pot where various generations (elder and younger) exchanged their knowledge and skills-learn from the experiences of their elders. Pashtun women have highlighted multiple functions of hujras. Hujra is not only taken as a guest room but they are utilized to serve the community both in good and hard terms.

Modern technological advancements have brought immense pressures and altered the dynamics of Pashtun society. Various technological gadgets such as mobile phones, computers, the internet, etc. have changed and replaced the place and concept of Hujra or baithak to a greater extent since everyone (elder and younger) has been addicted to using them in everyday life. Most of the respondents pinpointed the transitional phase of hujras that how modern technological advancements have replaced the hujra system among Pashtuns, especially the young Pashtun generation. It has become evident that now traditional hujras are converted into small baithaks where only guests are served and accommodated. The true essence of hujras has declined-as it was used to be a place where youngsters were supposed to gather and share their feelings, thoughts, and problems with elders. Nowadays, baithaks are no more celebrated in that way because the young generation is more attracted and occupied by social media like Facebook, WhatsApp, Instagram, and much more.

Likewise, Pashtun women defined and signified the indispensable function of Pashto proverbs in the transmission of Pashtunwali as they are interpreted and defined in a very realistic manner. Pashtun women shared the meanings and context of Pashto proverbs about the Pashtun character such as Pashtun is born at home and dies on the battlefield - reflects that Pashtun is mindful about the construction of their social status and identity. One of the old-aged adult-Tanzila, married, living in a joint family system mentioned a Pashto proverb representing the relationship and significance of the Pashtun value system for Pashtuns as irreplaceable-A Pashtun who does not follow his code of life should be buried in a grave and also shared some Pashto proverb depicted the notion of commitment expected out of Pashtuns as Pashtun knows only one way and Pashtun does everything but he forgets nothing (Personal Communication, 10-09-2019).

Deliberately, proverbs are statements that are backed by the wisdom and explain various facets of life based on the monumental experiences of the older generation. They are communicated to the next age figuratively and predictably. Young Pashtun women have also shared numerous Pashto proverbs that portray the profound sentiments and pride of Pashtuns concerning their ethnicity. Following are given a few maxims that portray these sentiments:

Pashtun looks good by maintaining honor and faithfulness.

A Pashtun who does not follow his code of life should be buried in a grave.

Pashtun eats his meal on the table of others.

When the Pashtun takes revenge after hundred years, even then he makes hurry,

Pashtun does not take a light burden.

The above precepts show some fundamental attributes of a Pashtun. These incorporate honors, grit, dependability, liberality. Pashtun women were of the view that they enthusiastically follow the standards of the Pashtun code of life, like vengeance, cordiality, and restraint.

Undoubtedly, Pashto proverbs are having extraordinary importance in the Pashtun cultural context. These proverbs reflect the hidden treasure of elder's wisdom. Talking particularly in women context, elder Pashtun women (mothers are grandmothers, mothers-in-law) try to transfer the traditional culture through the use of such proverbs while household chores. Most of the respondents shared the proverbs with reference to certain themes such as Pashtunwali, bravery, revenge, hospitality, patriotism, fate, ethics \& youth, etc. They pointed out that a household is a common place where Pashtun women exercise their hold and power (on the daily basis) in the capacity of mother, grandmother, and mother-in-law. Deliberately, they used to share proverbs with their daughters about situations and places to better guide them about the basic tents of Pashtunwali and expected outcomes - to become a dignified and modest Pashtun woman.

\section{DISCUSSION AND CONCLUSION}

The results of the present endeavor as discussed above, in general, provide a detailed analysis of the episteme and experiences of Pashtun women of various age groups about Pashtunwali and its core principles. It has become evident that Pashtun elder women especially the grandmothers and mothers have a pivotal place in explaining the Pashtunwali to the younger generation of Pashtun women. With their lifelong experiences, elder Pashtun women tend to guide their younger generation regarding the 
importance of Pashtunwali as a basic Pashtun code of conduct. The research findings revealed that the majority of the Pashtun women, irrespective of their socio-demographic background, identified multiple traits and principles which are recognized, practiced, and transmitted among Pashtun women throughout generations. These principles are defining the theme of their cultural heritage. Pashtun women consider their social heritage as something which is an ultimate source of knowledge, morality, and self-identification. They were very ethnocentric about their traditions, history, and ancestral values which are defined and practiced through ages.

The family system of Pashtuns is a major transmitter of Pashtunwali among young Pashtun generations. Though there is some variation in urban Pashtun culture nowadays yet there is a considerable impact on Pashtun kids from the family side. Younger generations of Pashtun are taught from their early childhood that they have to live their life understanding and implementing the traditional Pashtun code. Such primary socialization from family helps the young Pashtun women to comply with the standards of the Pashtun cultural context. This is further compounded by the fact that one of the important factors that transmit all cultural, social, and religious rituals is the family system of Pashtuns. The younger generation of women learns their entire traditional heritage through their ancestors. An important role is played by the Pashtun mothers. They are having quite dignified and celebrated status within society as pinpointed by Qadeer (2014) in his research on Pashtunwali and the status of women in Pashtun society. Elder Pashtun women are considered to be the guardian and custodians for the transmission of their culture, particularly for youngsters.

Pashtun women are very much concerned about their customs and feel proud of practicing those traditions. They show great admiration towards their value system. Among Pashtuns, kinship ties have been defined as part and parcel of Pashtunwali. Most of the respondents recognized their Pashtun culture as equated with their ultimate soul or existence. Some of them even shared that:

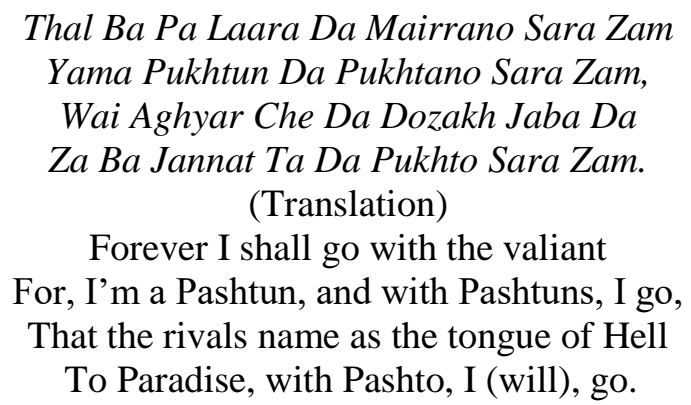

In Pashtun culture, notions of honor, dignity, and shame are described as driving fuel behind all cultural values and structures. Holistically, the study reflected the perspective of Pashtun women that they were appreciative and insightful about the meaning, history, and cultural composition of Pashtunwali and their identity but at the same time, they were not benighted about the contemporary emerging challenges that have been faced by traditional Pashtun culture.

\section{ETHICAL CONSIDERATIONS}

Academic research involves certain ethical standards (Bryman \& Bell, 2007). All the major ethical standards were followed during the research work. Informed consent was sought from the respondents. The participation of respondents was voluntary, and respondents were allowed to withdraw at any stage. The privacy and confidentiality of the data were ensured. The anonymity of the respondents and their organizations is maintained. Pseudonyms were adopted in this regard. The respondents were not harmed in any form and their dignity.

\section{CONFLICT OF INTEREST}

The authors declare that they have no conflict of interest with reference to this study.

\section{FUNDING}

This research work was self-supported. No funding was available.

\section{REFERENCES}

Agarwal, B. (1998). A field of one's own: Gender and land rights in South Asia. New York: Cambridge University Press. 
Ahmad, A. \& Boase, R. (2004). Pashtun Tales from the Pakistan-Afghanistan Frontier. Al Saqi Books.

Ahmad, A. (2006). Afghan Women: The State of Legal Rights and Security. Policy Perspectives, 2541.

Ahmad, A. S. (1980). Pukhtun economy and society: Traditional structure and economic development in a tribal society. Boston: Routledge \& Kegan Paul.

Ahmad, N., Ali, S. R., \& Bangash, A. K. Jadoon, M. A. (2020). The role of anti-Taliban Lashkar (armed militia) in the prevention of terrorism in conflict-affected areas. Pakistan Journal of Society, Education, and Language (PJSEL), 6(1), 94-102.

Ahmed, A. (1978). An aspect of the colonial encounter in the North-West Frontier Province. Asian Affairs, 9(3), 319-327.

Ahmed, A. (1980). Millennium and charisma among Pathans: A critical essay in social anthropology. London: Routledge.

Ahmed, A. (2004). The world is established through the work of existence: the performance of GhamKhadi among Pukhtun Bibiane in Northern Pakistan (Doctoral dissertation, University of Cambridge).

Ahmed, A. (2010). Women's Agency in Muslim Society. The SAGE Handbook of Islamic Studies, 22, 213.

Ahmed, A. (2013). Muslim tribes and the War on Terror. Speech transcript.

Ahmed, A. S. (1980). Pukhtun economy and society. London: Routledge.

Ahmed, A. S. (2004). Resistance and control in Pakistan. Routledge, Revised Edition.

Ahmed, A. S. (2013). The thistle and the drone: How America's war on terror became a global war on tribal Islam. Washington, DC: Brookings Institution Press.

Ahmed, A. (2006). Sorrow and joy among Muslim women: The Pukhtuns of Northern Pakistan. Cambridge: Cambridge University Press.

Ahmed, I. (2018). Emergence of the Pashtun Tahafuz Movement. Daily Times, OP-ED. Retrieved from https://dailytimes. com.pk/227740/emergence-of-the-Pashtun-tahafuz-movement.

Ahmed, L. (1992). Women and gender in Islam. Yale University Press.

Ahmed, M. S., Wahab, Z., \& Rehman, Z. (2017). Pukhtunwali and its Depiction in Pakistani Advertising. FWU Journal of Social Sciences, 11(2), 181-190.

Ahmed, M. S., Wahab, Z., \& Rehman, Z. (2017). Pukhtunwali and its Depiction in Pakistani Advertising. FWU Journal of Social Sciences, 11(2), 181-190.

Ahmed, Z. S., \& Yousaf, F. (2018). Pashtun jirgas, their potential in Pak-Afghan reconciliation and national reconstruction. South Asia Research, 38(1), 57-74.

Ahmed, Z. S., \& Yousaf, F. (2018). Pashtun Jirgas, their potential in Pak-Afghan reconciliation and national reconstruction. South Asia Research, 38, 57-74.

Ahmed, Z. S., Yousaf, F., \& Zeb, K. (2018). Socio-economic and political determinants of terrorism in Pakistan: University students' perceptions. International Studies, 55, 130-145.

Akbar, A. (2013). Thistle and Drone: America's War on Terror or War on Tribal Islam. Lahore: Vanguard Books.

Akbar, A. S. (1983). Pashtun society and economy. London, England: Routledge \& Kegan Paul.

Akbar, M. (1988). Revolution and counterrevolution in Afghanistan. Journal of Contemporary Asia, 18(4), 133-142.

Akhtar, M. (1997). Da Pakhto Mataloona (Pashto Proverbs). Swat: Shoaib Sons Publishers.

Akins, H. (2018). Pakistan's "Pashtun Spring” faces off against a colonial-era law. South Asia@ LSE. Retrieved from http://eprints.lse.ac.uk/89990/.

Alam, J., \& Ali, S. R. (2013). Honor: An Uncompromised Feature of Afridi Tribe. Journal of Law and Society, 44(63).

Alam, J., Ali, S. R., Shah, M., \& Jamal, H. (2014). Feud: An Arena of Pakhtunwali and Violence among Pakhtun of Afridi Tribe. FWU Journal of Social Sciences, 8(2), 37.

Alley, J. (2012). What is Pashtunwali? Retrieved from https://edukasipresenttime. blogspot.com/2012/02/is-pashtunwali.html

Anderson, J. W. (1979). Doing Pakhtu: Social Organization of the Ghilzai Pakhtun. Ph.D. dissertation. University of North Carolina, Chapel Hill. 
Atayee, I. (1979). A dictionary of the terminology of the Pashtun tribal customary law and usages. Kabul: The Academy of Sciences of Afghanistan.

Barth, F. (1969). Introduction. In: Fredrik Barth (ed.), Ethnic Groups and Boundaries. The Social Organization of Culture Difference. Oslo: Scandinavian University Press, pp. 9-38. Blom, Jan-Petter. 1969. Ethnic and cultural differentiation. In: Fredrik Barth (ed.), Ethnic Groups and Boundaries. The Social Organization of Culture Difference. Oslo: Scandinavian University Press, pp. 75-85.

Bartlotti, L. N. (2000). Negotiating Pakhto: Proverbs, Islam and the construction of identity among Pashtuns (Doctoral dissertation, The University of Wales, Lampeter). Chicago.

Benson, B. L., \& Siddiqui, Z. R. (2014). Pashtunwali-law for the lawless, defense for the stateless. International Review of Law and Economics, 37, 108-120.

Bokawee, M.A.S. (2006). The Pukhtoons. Rawalpindi: Pap- Printers.

Bryman, A. \& Bell, E. (2007). The ethics of management research: an exploratory content analysis. British journal of management, 18(1), 63-77.

Dupree, L. (1978). Language and politics in Afghanistan. Journal of Developing Societies, 11, 131.

Harding, S. (1991). Whose science? Whose knowledge? Thinking from women's lives. Ithaca, New York: Cornell University Press.

Hawkins, J. (2009). The Pashtun cultural code: Pashtunwali. Australian Defence Force Journal, 180, $16-27$

Hebblethwaite, S., \& Norris, J. (2011). Expressions of generativity through family leisure: Experiences of grandparents and adult grandchildren. Family Relations, 60(1), 121-133.

Idrees, A. (2005). Pakhtoonwalee: Code of Love and Peace. Peshawar: Danish Book Store Qissa Khwani Bazar.

Kakar, P. (2004). Tribal law of Pashtunwali and women's legislative authority. Retrieved from http://www.law.harvard.edu/ programs/ilsp/research/kakar.pdf

Kakar, P. (2007). Tribal law of Pashtunwali and women's legislative authority. Harvard Law School. Retrieved from http://www.rolc.sc.edu/sites/sc.edu.rolc/files/attachments/Tribal\%20Law\% 0of\%20Pashtunwali\%20and\%20Women's\%20Legislative\%20Authority_0.pdf.

Khalid, S. H. \& Mukbtar, M. E. (2002). The Future of Girls, Education in Pakistan. UNESCO office Islamabad.

Khan, U., Cheng, Y., Shah, Z. A., \& Ullah, S. (2020). Resistance in disguise and the re-construction of identity: a case of the Pashtuns in Pakistan. Inter-Asia Cultural Studies, 21(3), 374-391.

Lindholm, C. (1982). Generosity and jealousy: The Swat Pukhtun of Northern Pakistan. New York: Columbia University Press.

Naples, N. A., \& Gurr, B. (2013). Feminist empiricism and standpoint theory. Feminist Research Practice. London: Sage, 14-41.

Qadeer, A. (2014). The status of women in FATA: A comparison between Islamic principles and Pashtunwali. Scotts Valley, California: CreateSpace Independent Publishing Platform.

Qazi, A. (2009). Afghan Women's History. Retrieved from Afghanistan Online Web site: http://www.afghan-web.com/woman/afghanwomenhistory.html.

Sanauddin, N. (2015). Proverbs and patriarchy: analysis of linguistic sexism and gender relations among the Pashtuns of Pakistan (Doctoral dissertation, University of Glasgow).

Saeed, M. (2012). Pakhtun Men's Perceptions of the Conditions Promoting Domestic Violence in their Culture (Doctoral dissertation, University of York).

Smith, D. (1997). Comments on Heckman's "Truth and Method: Feminist standpoint revisitedSigns, 44(1), 7-13.

Spain, J. W. (1963). The Pathan borderland. The Hague: Mouton and Co.

Spain, J. W. (1972). The way of the Pathans. Karachi: Oxford University Press.

Swinehart, J. W. (1963). Socio-economic level, status aspiration, and maternal role. American Sociological Review, 391-399.

Yousafzai, H.M. \& Gohar, A. (2012). Towards Understanding Pashtun Jirga: An Indigenous Way of Peacebuilding [i.e., Peacebuilding] and More. Sang-e-Meel Publications. 